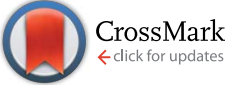

Cite this: RSC Adv., 2017, 7, 4876
Received 25th November 2016 Accepted 5th January 2017

DOI: $10.1039 / c 6 r a 27329 g$

www.rsc.org/advances

\section{Vermicomposting of coal fly ash using epigeic and epi-endogeic earthworm species: nutrient dynamics and metal remediation}

\begin{abstract}
Zeba Usmani, Vipin Kumar* and Sujeet Kumar Mritunjay
Huge amounts of coal fly ash (FA), produced during power generation, has led to several environmental problems associated with metal pollution and the burden of its disposal. Vermicomposting has emerged as a cost-effective technique in suitable management of FA. Two epigeic earthworm species: Eisenia fetida, and Eudrilus eugeniae and one epi-endogeic species: Lumbricus rubellus were selected for vermiremediation of coal FA. The investigation addresses the changes in the earthworm biomass, number, nutrient content and metal content in the treatments of FA amended with cow-dung (CD) at periodical intervals of vermicomposting. Metal ( $\mathrm{Cr}, \mathrm{Cu}, \mathrm{Cd}, \mathrm{Zn}, \mathrm{Ni}$ and $\mathrm{Pb}$ ) removal efficiency of the three earthworm species has been observed. Bioaccumulation factor (BAF) and changes in the microbiological fauna of the different mixtures were also witnessed. Earthworm and cocoon count showed an increase in trend with duration of vermicomposting. The concentration of total nitrogen, phosphorous and potassium increased in all the treatments. The maximum bacterial count $\left(8.0 \times 10^{5} \mathrm{CFU} \mathrm{g} \mathrm{g}^{-1}\right)$ and fungal count $\left(3.8 \times 10^{3} \mathrm{CFU} \mathrm{g}{ }^{-1}\right)$ were observed in FA + CD (1:3) mixture, comprising E. eugeniae. Significant reduction $(p<0.05)$ in the metal concentration of the treatments along with subsequent increase in metal content of earthworm tissues using Flame Atomic Absorption Spectrophotometer was observed. The treatment FA + CD $(1: 3)$ gave the best results in terms of nutrient enhancement and metal removal. Maximum metal reduction in the treatment, FA + CD (1:3) was 58.82\% for Cr by E. fetida, $71.94 \%$ for $\mathrm{Ni}$ by $E$. eugeniae, and $51.67 \%$ for $\mathrm{Cu}$ by $L$. rubellus. Highest BAF value was obtained for $\mathrm{Ni}$ (3.31) in $E$. eugeniae driven treatment FA + CD (1:3). The maximum metallothionein production was observed in $E$. eugeniae followed by E. fetida and L. rubellus.
\end{abstract}

\section{Introduction}

Rapid urbanization and industrialization have intensified the demand of electricity all over the world. Power has been regarded as an engine of growth in most of the developing countries. Major source of electrical energy is coal based thermal power plants, leading to hyperbolic use of coal, as the prime energy resource. Fly ash (FA) is a resultant of coal and lignite combustion $^{1}$ that enters the flue gas stream ${ }^{2}$ during electricity generation. FA is one of the most complex and anthropogenic material, leading to major environmental problems like soil, water, air pollution and disruption of ecological cycles. The growing energy demand would lead to various social, economic and environmental problems related to FA disposal. Thus, there is an urgent and ongoing need to develop novel methods for proper utilization and management of coal FA. Recycling of coal

Laboratory of Applied Microbiology, Department of Environmental Science and Engineering, Center of Mining Environment, Indian Institute of Technology (Indian School of Mines), Dhanbad, Jharkhand, India. E-mail: vipinmicro1@gmail.com; Tel: +919471191352
FA can be a good alternative than its disposal leading to economic and environmental benefits.

The physico-chemical and elemental properties of coal FA determines its utilization in different sectors of the economy. FA has great potentiality in agriculture and is quite economical to use as a soil amendment. ${ }^{3} \mathrm{FA}$ is a good source of essential plant nutrients like $\mathrm{Ca}, \mathrm{Mg}, \mathrm{S}, \mathrm{Si}, \mathrm{Al}, \mathrm{Fe}$, and $\mathrm{Na}$ that are beneficial for plant growth ${ }^{4}$ but it consists of certain heavy elements like Fe, Mn, As, Cr, Zn, Pb, Ni, Ba, Sr and V, some of which are of environmental concern even at low concentrations. ${ }^{5}$ Thus, the major constraints associated with the use of FA in agricultural ecosystem is the low availability of the nutrient elements basically N, P, K and lower rate of degradation of FA after application in soils. ${ }^{6}$ The other serious problem of utilizing FA for agricultural use is the predominance of heavy metals in the material and in soluble forms.,

Vermicomposting is an effective technique for mitigation of metals from FA. It is an environment-friendly and faster method of producing organic rich fertilizer from waste materials. ${ }^{9}$ Earthworms are potent for rapid and efficient decomposition of various industrial and organic wastes. ${ }^{10}$ They have the ability to convert waste materials into mineralized forms as 
vermicompost. Earthworm species such as Eisenia fetida, Lumbricus rubellus, and Eudrilus eugeniae have the potency to mechanically fragment waste material through their gizzard by increasing the surface area and positively modifying the biological activity during composting. E. fetida has shown its ability in increasing bioavailability of major nutrient elements such as $\mathrm{P}$ and $\mathrm{N}$ in $\mathrm{FA}^{\mathbf{1 1 , 1 2}}$ on one hand and minimizing the solubility of heavy metals on the other. ${ }^{13}$ The efficiency of E. eugeniae and $L$. rubellus in rapid degradation of waste material has been well documented by ${ }^{\mathbf{1 4 , 1 5}}$ respectively. Suthar et al. 2008 (ref. 16) reported about the heavy metal accumulation ability of earthworms in their tissues during vermicomposting. Numerous authors, reviewed by Hughes et al. 1980 (ref. 17) and Beyer 1981 (ref. 18) have reported that earthworms uptake and accumulate heavy metals such as $\mathrm{Cd}, \mathrm{Hg}$ and $\mathrm{Au}$ in their tissues, while living both in contaminated and non-contaminated environments. ${ }^{19}$ Dai et al. $(2004)^{20}$ reported that bioaccumulation of metals in worms is their ability to eliminate excess of metals. Metals accumulate in the chloragogen cells lying on the outerside of the earthworm's gut. ${ }^{21}$

Metallothionein (MT) is produced in earthworm's gut on exposure to heavy metals in their body. ${ }^{22} \mathrm{MT}$ is a metal binding ubiquitous protein. It plays an important part in homeostasis of metal ion and redox chemistry within the cells. ${ }^{23}$ MT has a binding capacity for several metals including $\mathrm{Cu}^{2+}, \mathrm{Mn}^{2+}$ and $\mathrm{Zn}^{2+}$ the metalloid $\mathrm{As}^{3+} \cdot{ }^{24} \mathrm{MT}$ release depends upon a number of factors: duration of exposure, metal concentration, the presence of specific metal ions and nature of feedstock. ${ }^{22}$

There are very few studies reported on the remediation of industrial wastes such as coal FA by the vermicomposting species and the comparison between the metal accumulation ability of the different earthworm species. The experiment involves the exposure of the three earthworm species to the vermicomposting system consisting a mixture of FA and cowdung (CD) in different ratios. The study emphasizes on (i) variations in biomass growth, count of earthworms and cocoon at different durations of vermicomposting. (ii) Accumulation and comparison of metals in the treatments and the three earthworm species. (ii) Deriving relation between the metal accumulation in the treatments and metal accumulation in the earthworm tissues based on regression equations. (iii) Bioaccumulation factor of metals in the earthworm species. (iv) Metallothionein (MT) protein production in the earthworm species on metal exposure from FA.

\section{Materials and methods}

\subsection{Sample collection}

FA samples were collected from electrostatic precipitator of Chandrapura thermal power station (CTPS), Jharkhand, India $\left(23^{\prime \prime} 73^{\prime} 72^{\circ} \mathrm{N}\right.$ and $\left.86^{\prime \prime} 12^{\prime} 56^{\circ} \mathrm{E}\right)$. Urine free, CD was collected from local area in order to expedite the bioconversion process. The earthworm species were collected from the vermiculture unit of the Vivekananda Institute of Biotechnology, Nimpith, Kolkata, India. The species selected for vermicomposting were two epigeic earthworm species, E. fetida and E. eugeniae and an epiendogeic earthworm species, L. rubellus. Mature (about 45-60 days old) healthy clitellated species of earthworms, comprising a weight of about 350-420 mg were collected. The species were brought to the laboratory in jute bags containing the feed material.

\subsection{Treatment design and vermicomposting system}

Rectangular plastic bins used were of size: $45 \mathrm{~cm}$ (length), $25 \mathrm{~cm}$ (width), $30 \mathrm{~cm}$ (height). The bottom of each bin was provided with twenty numbers of $100 \mathrm{~mm}$ holes for aeration and drainage purpose. CD and FA were air dried at room temperature. The combinations of FA and CD were thoroughly mixed and transferred $3 \mathrm{~kg}$ of these substrates in each bin. Coal FA was mixed with $\mathrm{CD}$ in different ratios along with the earthworm species as described in Table 1 . All the combinations were made in replicates of seven. The treatments were left for about 20 days before the inoculation of earthworms for thermal stabilization, initiation of microbial degradation and softening of substrate material in shady regions. 36 earthworms were inoculated in each bin. The optimum temperature and moisture content of the treatments were maintained at $25 \pm 2{ }^{\circ} \mathrm{C}$ and $60 \%$ respectively by sprinkling of water. The chemical and elemental composition were determined for the treatments at an interval of 30 days $(0,30,60,90$ days).

\subsection{Cocoon, earthworm count and biomass growth}

The number of cocoons and earthworms were periodically counted during vermicomposting by placing the samples on aluminium trays. Sieving was done in order to separate the earthworms from the white tiny cocoons. Biomass of the earthworms were measured at intervals using the method described by. ${ }^{25}$ The worms and cocoons were re-introduced in their respective substrate mixtures carefully, after counting and recording the earthworm biomass.

Table 1 Treatments and codes of different combinations of fly ash and cow-dung along with the species of earthworms (Eisenia fetida, Eudrilus eugeniae and Lumbricus rubellus) ${ }^{a}$

\begin{tabular}{ll}
\hline Code & Treatments \\
\hline Ef1 & FA alone + Eisenia fetida \\
Ef2 & FA + CD $(1: 1)+$ E. fetida \\
Ef3 & FA + CD $(1: 3)+$ E. fetida \\
Ef4 & FA + CD $(3: 1)+$ E. fetida \\
Ef5 & CD alone + E. fetida \\
Ee1 & FA alone + Eudrilus eugeniae \\
Ee2 & FA + CD $(1: 1)+$ E. eugeniae \\
Ee3 & FA + CD $(1: 3)+$ E. eugeniae \\
Ee4 & FA + CD $(3: 1)+$ E. eugeniae \\
Ee5 & CD alone + E. eugeniae \\
Lr1 & FA alone + Lumbricus rubellus \\
Lr2 & FA + CD $(1: 1)+$ L. rubellus \\
Lr3 & FA + CD $(1: 3)+$ L. rubellus \\
Lr4 & FA + CD $(3: 1)+$ L. rubellus \\
Lr5 & CD alone + L. rubellus
\end{tabular}

${ }^{a}$ FA: fly ash; CD: cow-dung; Ef: Eisenia fetida; Ee: Eudrilus eugeniae; Lr: Lumbricus rubellus. 


\subsection{Chemical analysis and nutrient evaluation}

The chemical parameters and nutrient content of the treatments were analyzed at an interval of $0,30,60$ and 90 days. $\mathrm{pH}$ ( $1: 2.5 \mathrm{w} / \mathrm{v}$ substrate : distilled water) was analyzed by a microprocessor based pH meter Esico model 1013. Electrical conductivity (EC, $\mathrm{dS} \mathrm{m}^{-1}$ ) was analyzed in the ratio of $1: 2(\mathrm{w} / \mathrm{v})$ by a digital conductivity meter (INSIF Electronics; IE-704). Total phosphorous (TP) was determined by Olsen's method. ${ }^{26}$ Total organic carbon (TOC) was determined by a rapid dichromate oxidation method ${ }^{27}$ and Total Kjeldahl nitrogen (TKN) was obtained by the method employed by. ${ }^{28}$ Total potassium (TK) analysis was carried out on extracts prepared according to ref. 29 and was estimated further by flame photometer.

\subsection{Microbiological analysis}

Bacterial and fungal colonies were isolated using serial dilution pour plate techniques. ${ }^{30}$ Nutrient Agar (Hi-media) and Rose Bengal Agar (Hi-media) were used to isolate bacterial and fungal colonies respectively. The colonies obtained on the Petriplates were counted with the help of a colony counter and the population (total bacterial and total fungal count) were expressed in terms of colony forming units (CFU $\left.\mathrm{g}^{-1}\right)$.

\subsection{Heavy metal analysis}

2.6.1. Vermicompost. The vermicompost was collected from different treatments at different stages of the vermicomposting cycle. Heavy metal content in the treatment containing FA solely was determined by the wet digestion method in a microwave digester (ETHOS One, Milestone Microwave Digester EPA 3546, Kawasaki, Japan) at $1000 \mathrm{~W}$ at $220^{\circ} \mathrm{C}$ for $1 \mathrm{~h}$ $0.2 \mathrm{~g}$ of homogenized sample was transferred into the Teflon vessel with a mixture of acids, $\mathrm{HNO}_{3}+\mathrm{HF}(5: 1) .{ }^{31}$ For other treatments (FA + CD), $0.5 \mathrm{~g}$ of sample was digested by adding $25 \mathrm{ml}$ of nitric acid in a microwave digester and heated for $4 \mathrm{~h}$ at 90-95 ${ }^{\circ} \mathrm{C}$ at $1000 \mathrm{~W}$. Samples were then transferred into $100 \mathrm{ml}$ polyethylene bottles through filter paper Whatmann 42\# and were analyzed by Flame Atomic Absorption Spectrophotometer (FAAS) (GBC AVANTA 3000) to determine heavy metal concentration. The standard reference material (SRM) 2690, National Institute of Standard and Technology, Ottawa, Canada (NIST) was used to check the validation of the results in the treatments Ef1, Ee1, Lr1. Method validation in case of other treatments (vermicompost) was done using soil standard NIST-SRM 2709.

2.6.2. Earthworm tissues. Earthworms were properly rinsed in distilled water and kept in Petri-dishes on moist filter paper in the dark for 4 days at $20 \pm 2{ }^{\circ} \mathrm{C}$ for gut clearance. The filter paper was changed repeatedly. The earthworms were kept in deep freeze at about $-10{ }^{\circ} \mathrm{C}$ in order to prevent microbial decomposition between collection and analysis. The earthworm tissues were oven dried at $80{ }^{\circ} \mathrm{C}$ for about $24 \mathrm{~h} .{ }^{32} \mathrm{Katz}$ and Jennis $^{33}$ method was applied to digest the earthworm tissues. The tissue samples were grounded in mortar pestle and burnt to ash at $550{ }^{\circ} \mathrm{C}$. The ash was placed in a test tube with $10 \mathrm{ml}$ of $55 \%$ nitric acid and was left overnight at room temperature for digestion to start. The samples were heated at a temperature of
$60{ }^{\circ} \mathrm{C}$ for $2 \mathrm{~h}$ and further heated at $120{ }^{\circ} \mathrm{C}$, till white fumes were obtained. The samples were allowed to cool and the solutions were filtered through whatmann filter paper $42 \#$ to $25 \mathrm{ml}$ using deionized water. Heavy metals were estimated by FAAS (GBC AVANTA 3000). The accuracy of analytical procedures for metal estimation in earthworm tissues was done by Mussel tissue NIST-SRM 2976. All metal concentrations for SRMs were within $10 \%$ of their certified values. The experiments were performed in compliance with the relevant laws and guidelines of Indian Institute of Technology (Indian School of Mines), Dhanbad, Jharkhand, India.

\subsection{Metallothionein radioassay}

The radioassay of earthworm gut tissue was carried out by the method employed by. ${ }^{34}$ The freeze killed worms were decolorized in $1.15 \% \mathrm{KCl}$ solution and a homogenate was obtained by using a glass Teflon homogenizer. ${ }^{35} \mathrm{Hg}^{203}$ was added to about $1 \mathrm{ml}$ of the homogenate. About $10 \%$ of $1 \mathrm{ml}$ trichloroacetic acid was added to a mixture of $\mathrm{Hg}$ and homogenate. The solution was made to stand for about $15 \mathrm{~min}$ to bring about the precipitation of metallothienic lacking protein. Centrifugation of the entire mixture was done at $5000 \mathrm{rpm}$ for about $10 \mathrm{~min}$ $0.4 \mathrm{ml}$ of the supernatant was assorted with about $4 \mathrm{ml}$ of scintillation fluid i.e., cocktail. A Perkin Elmer 1220 Liquid scintillation counter from HESCO research laboratories, India was used for determining the radioactivity. The radioactivity content was used as an estimate of MT and was expressed in terms of nanomoles per $\mathrm{g}$. The validation of the assay was performed by using the gel-filtration method.

\subsection{Estimation of bioaccumulation factor (BAF)}

Metal accumulation in earthworm tissues was evaluated with respect to BAF. The factor was determined with respect to the body tissues of earthworm species: E. fetida, E. eugeniae and $L$. rubellus and metal concentration in the respective substrates. Montouris et al. (2002) ${ }^{36}$ method was employed for estimation of BAF using the following formula:

$$
\mathrm{BAF}=C_{\text {biota }} / C_{\text {substrate }}
$$

where, $C_{\text {biota: }}$ metal concentration in earthworm tissues; $C_{\text {substrate }}$ : metal concentration in the respective treatments.

\subsection{Statistical analysis}

The statistical analyses were performed to determine mean and standard deviation by the use of the XLSTAT package of MS Excel 2010. One way ANOVA was performed to determine significant differences between the biomass growths of earthworms at different time intervals of vermicomposting process. Significant differences in the number of earthworms and cocoons in different treatments were observed using Duncan's multiple range test (ANOVA). Student's $t$ test was performed to obtain significant differences between mean of the metal concentrations before $\left(0^{\text {th }}\right.$ day) and after $\left(90^{\text {th }}\right.$ day) vermicomposting. Post hoc Tukey's test and Duncan's multiple range tests were performed to observe variations in the chemical 
properties and nutrient content with different time intervals and also to examine the significant differences in the mean metal concentrations of earthworm tissues among different treatments. Linear regression models were applied to determine the degree of variance in concentration of metals in the substrates and the earthworms.

\section{Results and discussion}

\subsection{Variations in biomass, population of earthworms and cocoon production}

The changes in biomass of earthworm species at different time intervals of $0,30,60$ and 90 days are depicted in Fig. 1. An increase in the trend of earthworm biomass of different species was observed to increase in the vermicomposting period. Maximum significant $(p<0.05)$ increase in biomass was observed at $90^{\text {th }}$ day of biological composting process. Poor biomass growth of earthworms was observed in the treatment comprised solely of FA. This may be due to difficulty in proper movement of earthworms in sole FA treatments due to its compact structure, thus reducing their reproduction rate. $E$. eugeniae showed a maximum increase in biomass followed by $E$. fetida and L. rubellus in FA + CD (1:3).

There was a considerable increase in the number of earthworms and cocoons with increase in the duration of vermicomposting (Fig. 2 and 3). E. eugeniae was observed to have the most rapid growth with maximum number of cocoon production. E. eugeniae has high reproductive rates and has the capacity to decompose large quantities of organic wastes rapidly. ${ }^{37}$ The treatments Ef2, Ef3 and Ef5 for E. fetida, Ee2, Ee3 and Ee5 for E. eugeniae; Lr2, Lr3 and Lr5 for L. rubellus showed the significantly $(p<0.05)$ preeminent results in terms of earthworm growth and cocoon production. Growth of earthworms might be affected by suitable environment, availability of food and feed stock density of the earthworms. ${ }^{38,39}$ FA and CD mixtures $(1: 1)$ and $(1: 3)$ were found to be most compatible mixtures for earthworm growth and cocoon production.

\subsection{Variations in chemical properties and nutrient contents}

3.2.1. $\mathrm{pH}$ and electrical conductivity (EC). A shift in $\mathrm{pH}$ can be observed in Fig. 4a, 5a and 6a in treatments comprising $E$. fetida. Coal FA from CTPS had a slight basic pH. A slight increase and finally a decrease in the $\mathrm{pH}$ values were observed in almost all the treatments (Fig. 4a, 5a and 6a). Similar results related to $\mathrm{pH}$ reduction during vermicomposting was observed by. ${ }^{40,41}$ Initial increase in $\mathrm{pH}$ may be due to alkaline humates and aluminium complexes and its further reduction due to production of humic and fulvic acid during vermicomposting associated decomposition of the substrates. ${ }^{42}$ Moreover, many
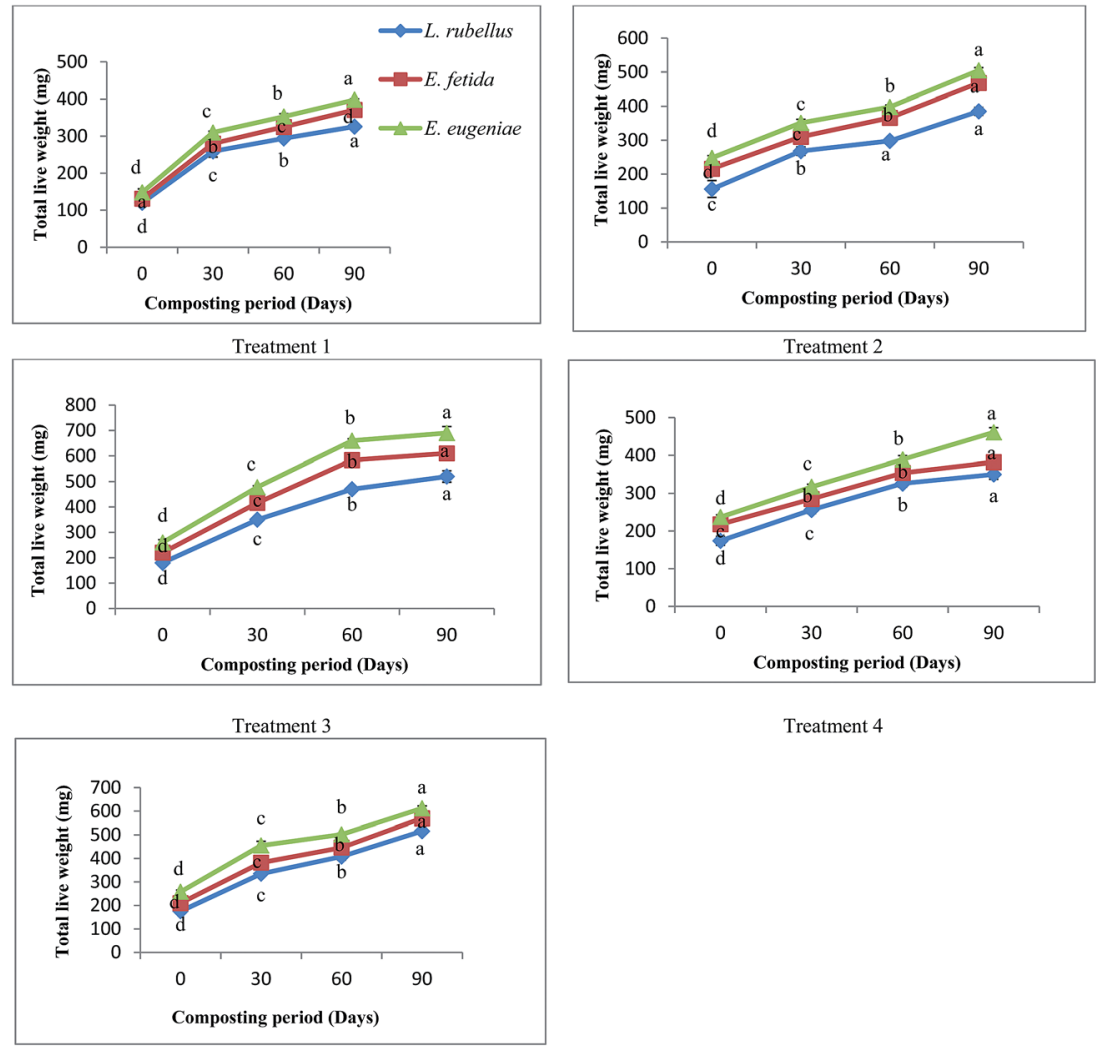

Treatment 4

Treatment 5

Fig. 1 Biomass growth of the earthworm species during vermicomposting at different intervals. Treatment 1: FA alone; treatment 2: FA + CD (1: 1); treatment 3: FA + CD (1:3); treatment 4: FA + CD (3:1); treatment 5: CD alone. Error bars represent standard deviation; values are in mean $\pm \mathrm{SD}(n=7)$. Different letters in the line graphs with each colour indicates significant differences in biomass growth of individual species at different time intervals at $p<0.05$ according to Duncan's multiple range test (ANOVA). 


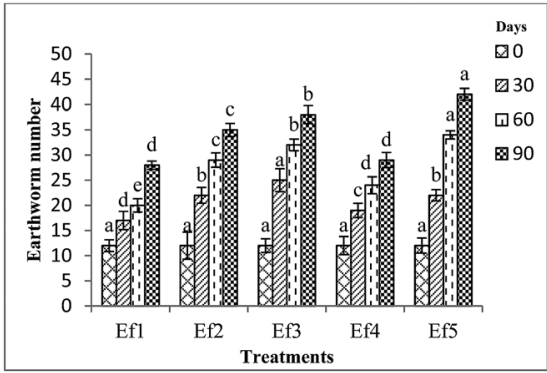

(a)

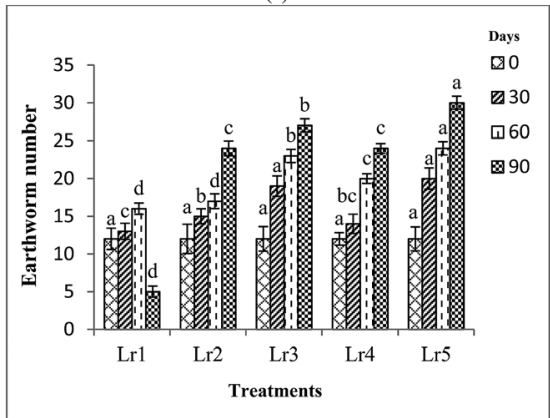

(c)

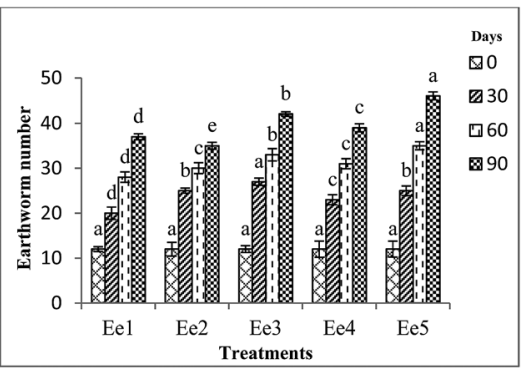

(b)

Fig. 2 Changes in the number of earthworms in the treatments at different intervals of vermicomposting process. (a) Eisenia fetida; (b) Eudrilus eugeniae; (c) Lumbricus rubellus. Error bars represents standard deviation; values are in mean $\pm \mathrm{SD}(n=7)$. Different letters in the bars with similar pattern indicates significant differences $(p<0.05)$ in the number of earthworms of the different treatments at the same time interval according to Duncan's multiple range test (ANOVA).

intermediate organic acids are produced that result in reducing the $\mathrm{pH}$ of the treatments.

An initial increase in EC values was observed in almost all the treatments (Fig. 4b, 5b and 6b) upto 30-60 days. Decomposition of organic substances leads to the release of mineral salts like phosphates and ammonia, which may lead to an initial increase in EC values. A sudden decline in EC values was observed after this duration. Subsequent decrease in EC values at the end of vermicomposting may be due to precipitation of mineral salts and volatilization of ammonia. ${ }^{43}$ Significant
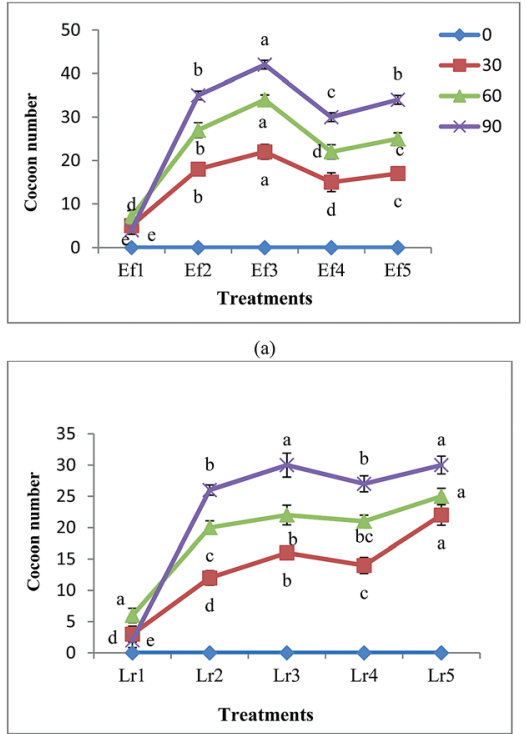

(c)

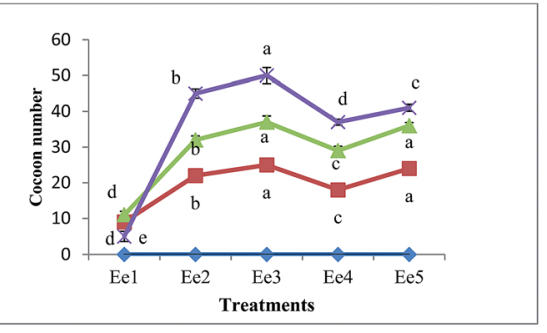

(b)

Fig. 3 Cocoon production by the earthworm species in the treatments during vermicomposting at different intervals. (a) Eisenia fetida; (b) Eudrilus eugeniae; (c) Lumbricus rubellus. Error bars represents standard deviation; values are in mean \pm SD $(n=7)$. Different letters at the data points of the line graphs with individual colour represents significant differences $(p<0.05)$ in the number of cocoon of different treatments at a particular time interval of 0, 30,60 and 90 days as per Duncan's multiple range test (ANOVA). 
differences were found in EC values of the treatments at intervals of 0,30, 60 and 90 days (ANOVA and Tukey's test; $p<0.05$ ).

3.2.2. Total organic carbon, Kjeldahl nitrogen, phosphorous and potassium. A significant decrease in TOC was observed throughout the treatments. A significantly higher decline in TOC was noticed by E. eugeniae followed by E. fetida and $L$. rubellus. A considerable decrease in TOC was observed in treatments Ef2 and Ef3 by E. fetida (Fig. 4c) and Ee2 and Ee3 by E. eugeniae (Fig. 5c) while, a subsequent less decrease in TOC was observed by L. rubellus (Fig. 6c). Garg et al. (2006) ${ }^{44}$ also observed the decline in TOC with duration of vermicomposting. Crawford 1983 (ref. 45) investigated that the decrease in TOC was the resultant of carbon loss. Dominguez $(2004)^{46}$ stated that vermicomposting is a joint operation of earthworms and microorganisms involving fragmentation and homogenization of the ingested material by the earthworms through muscular action of their foregut. This in turn leads to addition of enzymes and mucus to the ingested material thereby, increasing the surface area for microbial action. This biotic mutuality leads to loss of carbon in the form of $\mathrm{CO}_{2}$ during decomposition and mineralization of the substrates. ${ }^{47,48}$ The respiratory activity ${ }^{49}$ and high assimilation capacity of the earthworms further contributes to the decrease in TOC levels. An increase in the number of earthworms and consequently increase in microbial proliferation in the vermicomposts may have also resulted in decrease in TOC. $^{49}$ Suthar and Singh $(2008)^{50}$ reported that decline in TOC of the substrate mixture was followed by subsequent increase in the $\mathrm{N}$ content.

TKN content increased significantly in all the treatments with an increase in vermicomposting duration. In E. fetida, maximum increase in TKN content was observed in Ef5 followed by Ef3 $>$ Ef2 $>$ Ef4 $>$ Ef1. High TKN values were observed at $90^{\text {th }}$ day of vermicomposting in Ee5 (5.56\%), Ee3 (5.54\%) and Ee2 (5.24\%) by $E$. eugeniae and Lr3 (3.43\%) and Lr2 (1.9\%) by L. rubellus (Fig. $4 \mathrm{~d}, 5 \mathrm{~d}$ and $6 \mathrm{~d}$ ). The increase in TKN values might be due to loss in carbon and organic matter mineralization. ${ }^{51-53}$ Earthworms enhance $\mathrm{N}$ level in the vermicompost by adding their excretory products, mucus, body fluids and enzymes ${ }^{54,55}$ along with rapid microbial mineralization. ${ }^{38}$ Hartenstein and Hartenstein 1981 (ref. 56) reported that decrease in $\mathrm{pH}$ may be an important factor in retaining $\mathrm{N}$ in the substrates as $\mathrm{N}$ is lost as ammonia at higher $\mathrm{pH}$. Earthworms pose a great impact on $\mathrm{N}$ transformations through modifications of the environmental conditions and their interaction with microbes. They bring about mineralization of $\mathrm{N}$, thereby resulting in conditions that favor nitrification, causing rapid conversion of ammonium-nitrogen into nitrates..$^{9,41,57,58}$ However, Gaur and Singh (1995) ${ }^{59}$ and Kaviraj and Sharma (2003) ${ }^{52}$ reported that final content of $\mathrm{N}$ in vermicompost is dependent on initial $\mathrm{N}$ present in the substrate and the extent of decomposition.

TP showed an increase in trend (Fig. 4e, 5e and 6e) during different time intervals of vermicomposting. High TP were found in Ef3 (FA + CD; $1: 3$ ) and Ef5 (CD alone), comprising $E$.
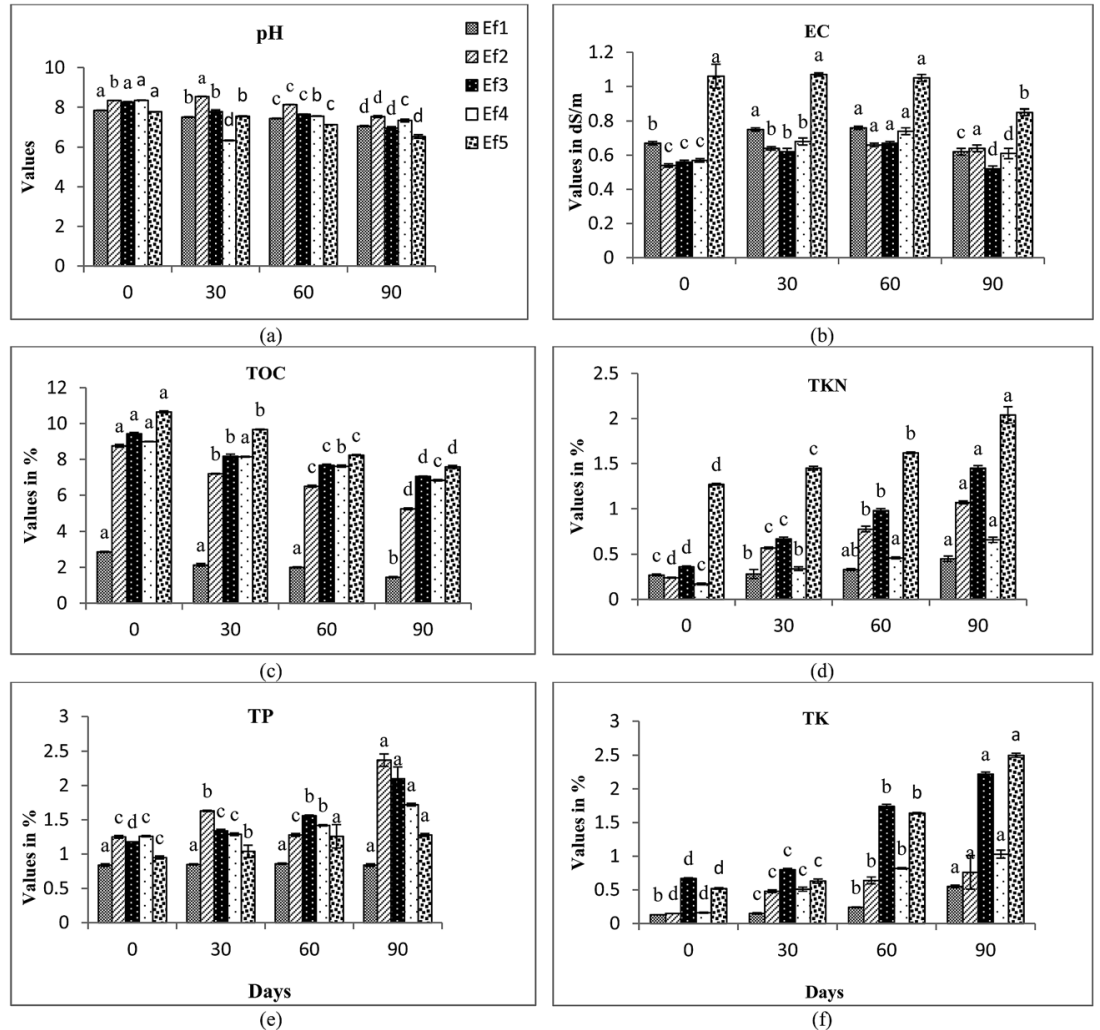

Fig. 4 (a-f) Variations in chemical properties and nutrient content of different treatments comprising Eisenia fetida at various time intervals of the vermicomposting process. Error bars represent standard deviation; values are in mean $\pm \operatorname{SD}(n=7)$. Different letters in the bars of similar pattern represent significant variation (at $p<0.05$ ) in the chemical characteristics and nutrient content of the individual treatments at different time intervals of the vermicomposting process according to Duncan's multiple range ANOVA test and post hoc Tukey's test. 

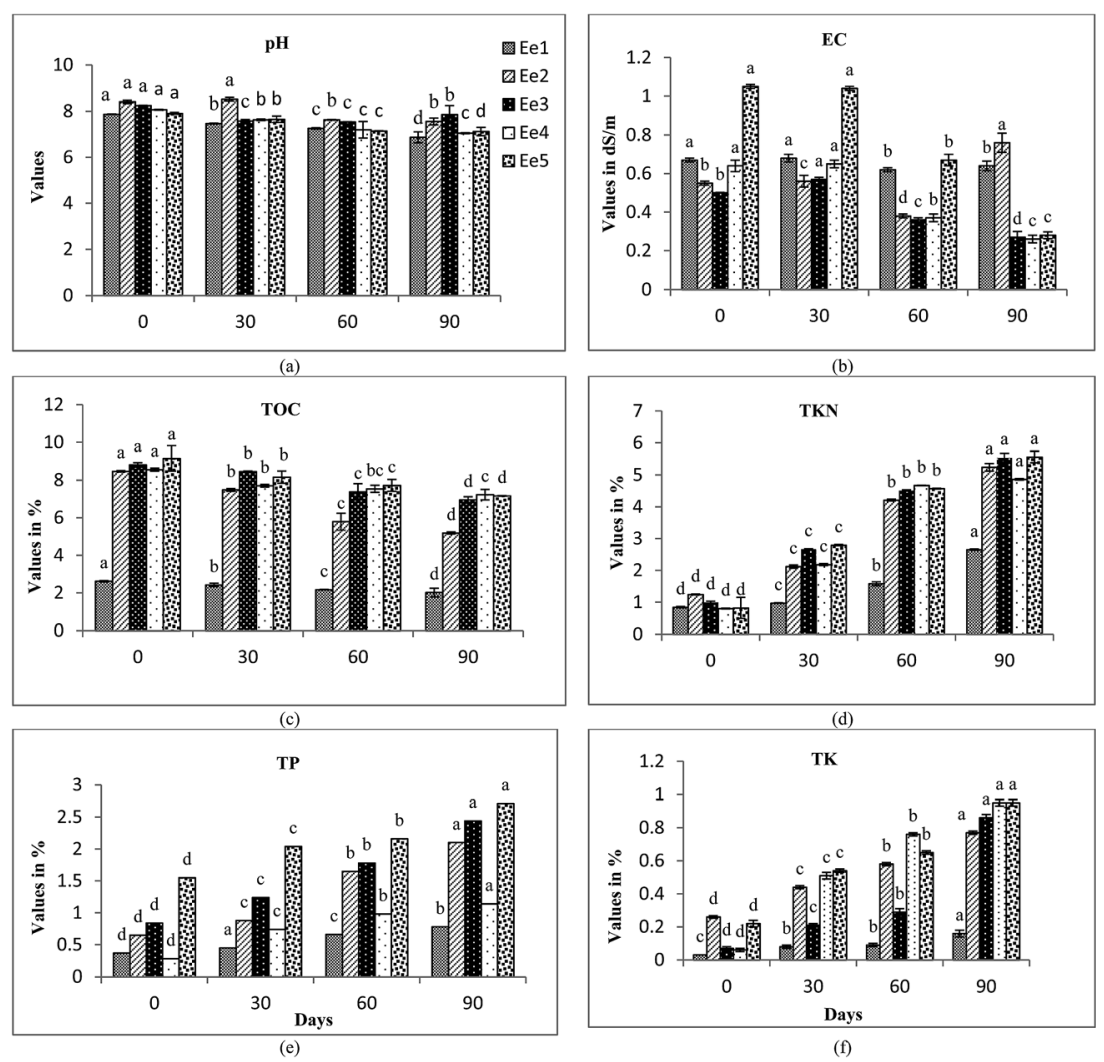

Fig. 5 (a-f) Variations in chemical properties and nutrient content of different treatments comprising Eudrilus eugeniae at various time intervals of the vermicomposting process. Error bars represent standard deviation; values are in mean \pm SD $(n=7)$. Different letters in the bars of similar pattern represent significant variation (at $p<0.05$ ) in the chemical characteristics and nutrient content of the individual treatments at different time intervals of the vermicomposting process according to Duncan's multiple range ANOVA test and post hoc Tukey's test.

fetida. The maximum TP was noticed in treatments comprising E. eugeniae. Ghosh et al. 1999 (ref. 60) revealed that vermicomposting has proved to be an effective technology in providing good phosphorous nutrition. Earthworms have the capability to convert phosphorous into soluble forms from their insoluble state. ${ }^{61}$ Satchell and Martein (1984) ${ }^{62}$ attributed that increase in $\mathrm{P}$ is the result of direct action of earthworms' gut enzymes and indirectly by stimulation of the microflora. Edwards and Lofty (1972) ${ }^{63}$ suggested that increase in TP during vermicomposting may be possibly because of mineralization and mobilization of $\mathrm{P}$ as a result of bacterial and faecal phosphatase activity of earthworms.

TK showed significant increase in trend throughout vermicomposting. Maximum increase in treatments were driven by $E$. eugeniae followed by L. rubellus and E. fetida (Fig. 4f, $5 \mathrm{f}$ and $6 \mathrm{f}$ ). The treatments Ef3 and Ef5 of E. fetida, Ee5, and Ee4 of E. eugeniae and Lr5 and Lr3 of L. rubellus showed significant higher TK values in comparison to the other treatments. It might be due to conversion of complex organic matters to simpler forms, that becomes more easily and readily available to earthworm's gut, ${ }^{64}$ resulting in the higher availability of potassium. Garg et al. (2006) ${ }^{44}$ also observed higher TK values in the vermicompost compared to the initial substrate mixture. They further reported that microbial flora influences the level of $\mathrm{K}$ and acid production by these microorganisms is an important mechanism for solubilization of insoluble $\mathrm{K}$.
There was considerable improvement in the micronutrient content (NPK) in the treatments with increase in vermicomposting duration. However, E. eugeniae showed maximum enhancement of nutrient contents in FA + CD $(1: 3)$ and FA + CD $(1: 1)$. Similar results were reported by. ${ }^{\mathbf{1 2 , 6 5}}$

\subsection{Variations in microbiological fauna}

High diversity in microbiological fauna was observed across the treatments, except in FA alone, which may be due to slow growth and reproduction of earthworms in that particular treatment. Higher microbial diversity was noticed in the treatments comprising E. eugeniae followed by E. fetida and $L$. rubellus. Amongst the treatments, Ee3 showed the maximum microbial diversity followed by Ee5 and Ef3 (Table 2). Maximum number of fungal strains were observed in the treatment Ee3 (FA + CD; $1: 3)$, followed by Ee2 (FA + CD; $1: 2$ ) (Table 3 ). Previous researchers have also reported that, the combination of FA and organic amendment improves the microbial functions. ${ }^{66,67}$ The maximum bacterial count $(8.0 \times$ $\left.10^{5} \mathrm{CFU} \mathrm{g}^{-1}\right)$ and fungal count $\left(3.8 \times 10^{3} \mathrm{CFU} \mathrm{g}^{-1}\right)$ were observed for the treatment Ee3. 11 bacterial strains were observed in the treatment FA + CD (1:3), comprising $E$. eugeniae, 9 bacterial strains in case of E. fetida and 7 bacterial strains were observed in case of $L$. rubellus for the similar treatment. 

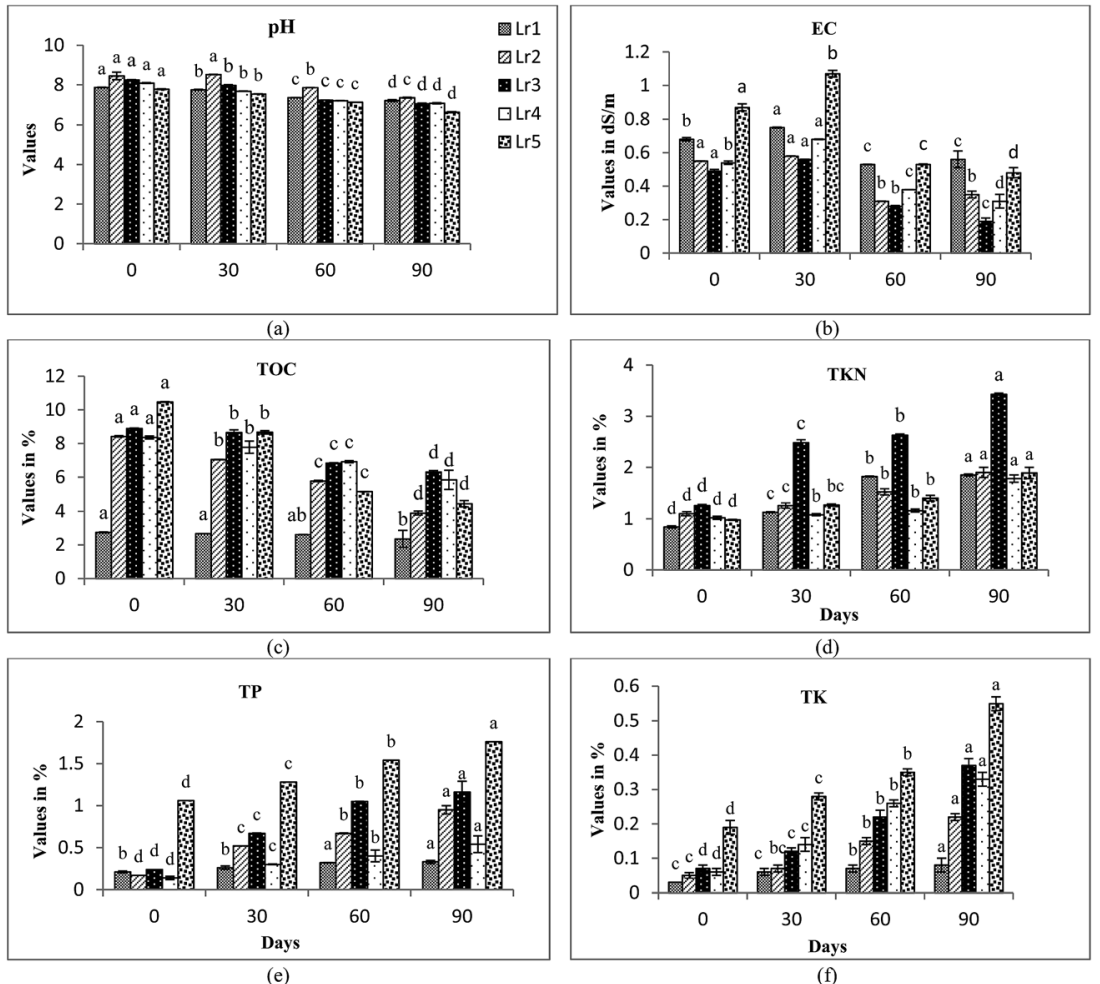

Fig. 6 (a-f) Variations in chemical properties and nutrient content of different treatments comprising Lumbricus rubellus at various time intervals of the vermicomposting process. Error bars represent standard deviation; values are in mean $\pm \operatorname{SD}(n=7)$. Different letters in the bars of similar pattern represent significant differences (at $p<0.05$ ) in the chemical characteristics and nutrient content of the individual treatments at different time intervals of the vermicomposting process according to Duncan's multiple range ANOVA test and post hoc Tukey's test.

Table 2 Variation in the microbial fauna of vermicomposted mixtures produced by Eisenia fetida, Eudrilus eugeniae and Lumbricus rubellus ${ }^{a}$

\begin{tabular}{lcc}
\hline Treatments & $\begin{array}{l}\text { Bacterial count } \\
\left(\text { value } \times 10^{4} \mathrm{CFU} \mathrm{g}^{-1}\right)\end{array}$ & $\begin{array}{l}\text { Fungal count } \\
\left(\text { value } \times 10^{2} \mathrm{CFU} \mathrm{g}^{-1}\right)\end{array}$ \\
\hline Ef1 & $38^{*}$ & $10^{\#}$ \\
Ef2 & 60 & 20 \\
Ef3 & 70 & 34 \\
Ef4 & 48 & 18 \\
Ef5 & 66 & 27 \\
Ee1 & $55^{*}$ & $21^{\#}$ \\
Ee2 & 67 & 24 \\
Ee3 & 80 & 38 \\
Ee4 & 58 & 19 \\
Ee5 & 75 & 32 \\
Lr1 & $22^{*}$ & $8^{\#}$ \\
Lr2 & 48 & 20 \\
Lr3 & 64 & 25 \\
Lr4 & 38 & 19 \\
Lr5 & 56 & 22
\end{tabular}

${ }^{a} \mathrm{CFU}$ : colony forming unit, *value $\times 10^{2} \mathrm{CFU} \mathrm{g}^{-1},{ }^{\#}$ value $\times 10^{1} \mathrm{CFU} \mathrm{g}^{-1}$.

\subsection{Variations in metal concentration during vermicomposting}

3.4.1. Metal content in treatments. Table 4 depicts the concentration of metals in the treatments before $\left(0^{\text {th }}\right.$ day) and after vermicomposting ( $90^{\text {th }}$ day). There were significant differences in the metal bioavailability of treatments from the initial day of vermicomposting. E. fetida and E. Eugeniae have the capability to bring about rapid degradation of FA and cowdung mixtures. A significant reduction in the concentration of metals such as $\mathrm{Cu}, \mathrm{Zn}, \mathrm{Cr}$ and $\mathrm{Pb}$ was observed in the treatments after the vermicomposting. E. eugeniae was found to be very effective in reduction of metal concentration for treatments Ee3 and Ee2. Reduction of $\mathrm{Cr}$ in the treatments Ef 2 and Ef3 by $E$. fetida was $38.28 \%$ and $58.82 \%$, respectively. $E$.

Table 3 Number of bacterial and fungal strains obtained in different treatments after vermicomposting

\begin{tabular}{lcl}
\hline Treatments & Bacterial strains & Fungal strains \\
\hline Ef1 & 2 & 0 \\
Ef2 & 8 & 2 \\
Ef3 & 9 & 2 \\
Ef4 & 3 & 1 \\
Ef5 & 5 & 1 \\
Ee1 & 3 & 0 \\
Ee2 & 6 & 2 \\
Ee3 & 11 & 3 \\
Ee4 & 4 & 1 \\
Ee5 & 7 & 1 \\
Lr1 & 0 & 0 \\
Lr2 & 5 & 1 \\
Lr3 & 7 & 2 \\
Lr4 & 3 & 0 \\
Lr5 & 4 & 1
\end{tabular}


Table 4 Changes in the metal concentration of the treatments comprising different earthworm species before $\left(0^{\text {th }}\right.$ day) and after vermicomposting $\left(90^{\text {th }} \text { day }\right)^{a}$

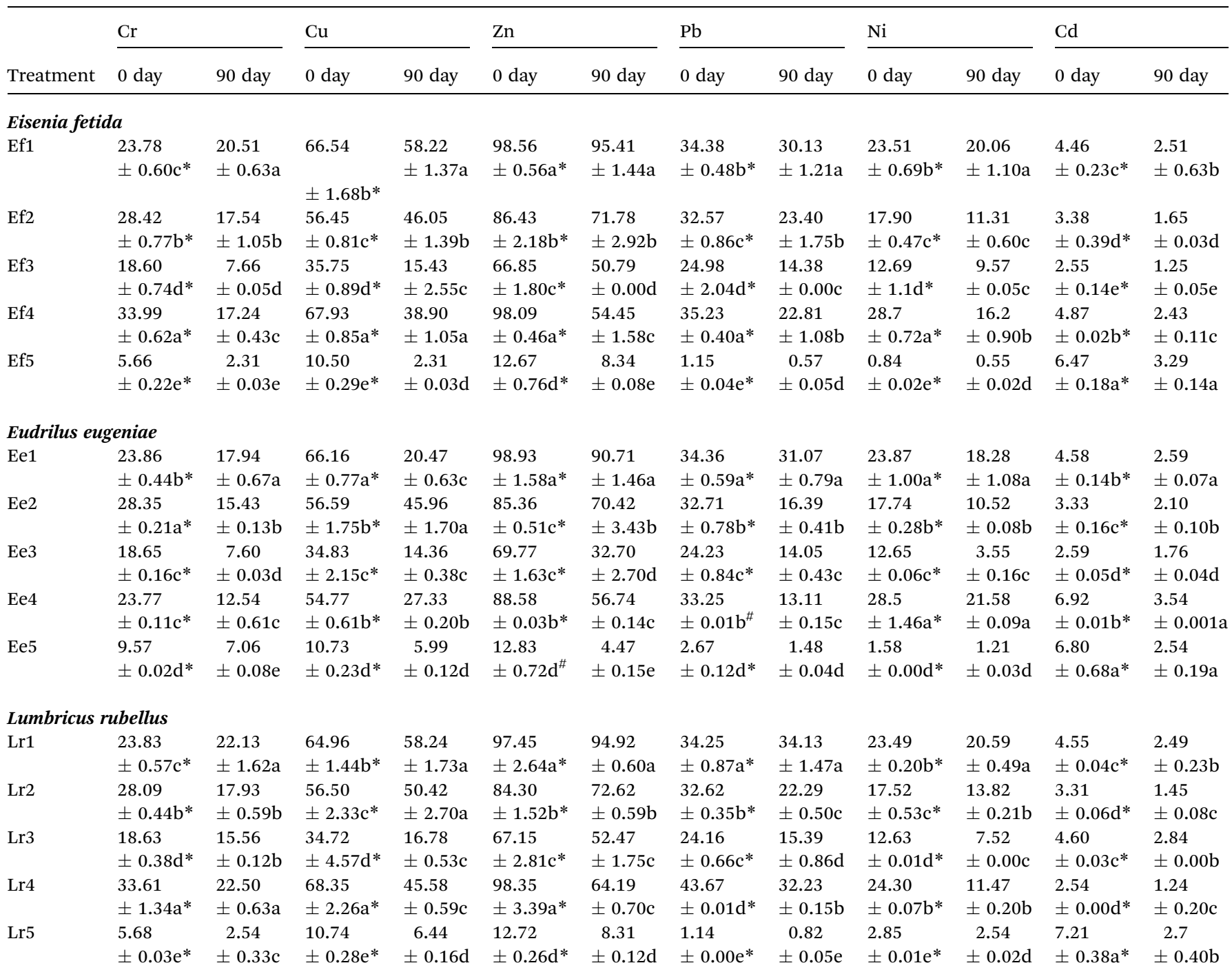

${ }^{a}$ Values are in mean $\pm \mathrm{SD}(n=7)$. Different letters in blue colour indicate significant differences (at $\left.p<0.05\right)$ in the mean metal concentrations of the different treatments before vermicomposting (0 day), according to Duncan's multiple range test (ANOVA) and post hoc Tukey's test. Different letters in purple colour represent significant differences (at $p<0.05$ ) in the mean metal concentrations of the different treatments after vermicomposting $\left(90^{\text {th }}\right.$ day) as per Duncan's multiple range test (ANOVA) and Tukey's test. *Significant differences $(p<0.05)$ between means of metal concentrations in the substrates before $\left(0^{\text {th }}\right.$ day) and after vermicomposting ( $90^{\text {th }}$ day) (student's $t$-test).

eugeniae reduced $\mathrm{Cr}$ concentration up to $59.25 \%$ while, L. rubellus up to $16.48 \%$. Cu concentration was reduced to more than $50 \%$ in Ef3, Ee3 and Lr3 by the three species of earthworms. Significant reduction in $\mathrm{Zn}$ and $\mathrm{Pb}$ were noticed by E. fetida and E. eugeniae. E. fetida reduced Cd upto $50.98 \%$, showing an affinity towards Cd while, L. rubellus and $E$. eugeniae reduced $\mathrm{Cd}$ upto $38.26 \%$ and $32 \%$ respectively. $E$. eugeniae showed remarkable results by reducing $\mathrm{Ni}$ upto 72.33\% for Ee3. Gupta et al. 2005 (ref. 13) and Bhattacharya and Chattopadhyay 2006 (ref. 68) demonstrated the role of earthworms in mitigating the toxicity of FA. Niyazi et al. 2014 (ref. 69) observed a decrease in heavy metal concentrations of the final vermicompost on inoculation of earthworms. ${ }^{70}$ The significant reduction in metal concentration of the compost during vermicomposting has also been reported by. ${ }^{71,72}$
Goswami et al. (2016) ${ }^{73}$ reported a steady decline in the total metal content in the vermicomposted products suggesting that, a considerable amount of metals may be accumulated by the earthworms.

Earthworms play a vital role in immobilization of metals by the process of metal detoxification via vermiremediation technology. This occurs due to two probable reasons. Firstly the earthworm mediated biodegradation process increases the level of humic fractions, that strongly immobilize the formation of stable metal-humus complexes ${ }^{74}$ and secondly, the metal chelating metallothionein proteins, present in the gut of earthworms bind metals as per the pathway described by. ${ }^{75}$ Improvement in the degree of humification indicates the formation of highly stable aromatic compounds, which have great potential for metal sequestration. ${ }^{74,76}$ 

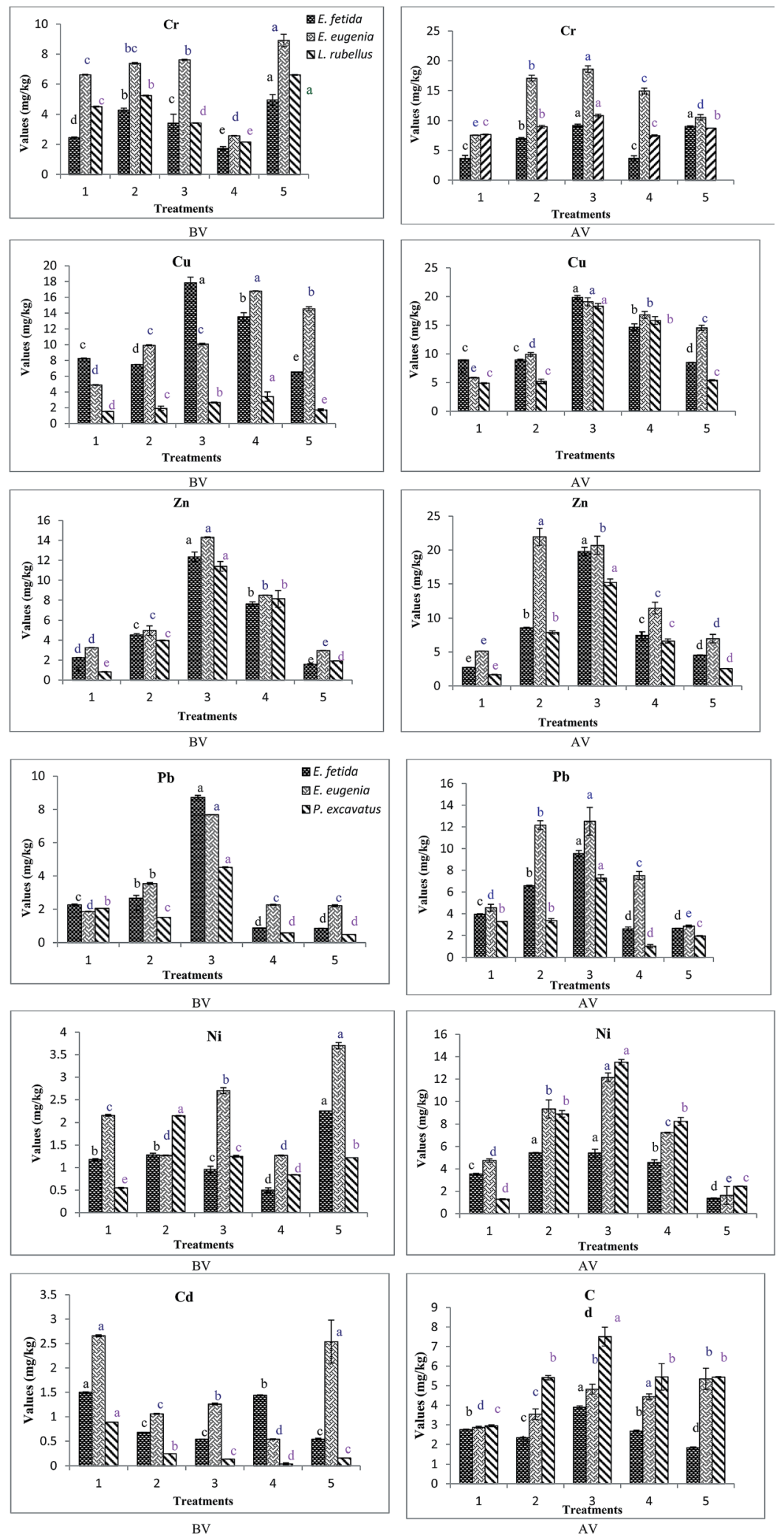

Fig. 7 Fluctuations in metal concentrations of the earthworm tissues in different treatments before and after vermicomposting. Treatment 1: FA alone; treatment 2: FA + CD (1:1); treatment 3: FA + CD (1:3); treatment 4: FA + CD (3: 1); treatment 5: CD alone. Different letters in black colour represents significant differences $(p<0.05)$ in mean metal concentrations of Eisenia fetida in different treatments as per ANOVA and Tukey's test; different letters in blue colour represents significant differences $(p<0.05)$ in mean metal concentrations of Eudrilus eugeniae in different treatments as per ANOVA and Tukey's test; values are in mean \pm SD $(n=7)$. Different letters in purple colour represents significant differences $(p<0.05)$ in mean metal concentrations of Lumbricus rubellus (ANOVA; Tukey's test). 
Table 5 Linear regression model, determination coefficient and significance levels with $\mathrm{Cr}, \mathrm{Cu}, \mathrm{Zn}, \mathrm{Pb}, \mathrm{Ni}, \mathrm{Cd}$ concentration in Eisenia fetida, Eudrilus eugeniae and Lumbricus rubellus as predictor variables. Metal concentration in the substrates served as dependent variables. Models consisting of significant predictor variables are only shown ${ }^{a}$

\begin{tabular}{lll}
\hline Model & $R^{2}$ & Significance
\end{tabular}

\section{Eisenia fetida}

$[\mathrm{Cr}]_{\mathrm{S}}=24.72-1.94 *[\mathrm{Cr}]_{\mathrm{Ef}}$

$[\mathrm{Cu}]_{\mathrm{S}}=48.16-0.02 *[\mathrm{Cu}]_{\mathrm{Ef}}$

$0.53 \quad 0.17$

$[\mathrm{Zn}]_{\mathrm{S}}=60.74-0.53 *[\mathrm{Zn}]_{\mathrm{Ef}}$

0.08

0.012

0.004

0.64

$[\mathrm{Pb}]_{\mathrm{S}}=17.00+0.25^{*}[\mathrm{~Pb}]_{\mathrm{Ef}}$

0.25

0.86

$[\mathrm{Ni}]_{\mathrm{S}}=2.61+2.18 *[\mathrm{Ni}]_{\mathrm{Ef}}$

$[\mathrm{Cd}]_{\mathrm{S}}=4.40-0.81 *[\mathrm{Cd}]_{\mathrm{Ef}}$

0.60

0.40

0.13

\section{Eudrilus engeniae}

$[\mathrm{Cr}]_{\mathrm{S}}=17.04-0.36 *[\mathrm{Cr}]_{\mathrm{Ee}}$

$[\mathrm{Cu}]_{\mathrm{S}}=36.16-1.00 *[\mathrm{Cr}]_{\mathrm{Ee}}$

$[\mathrm{Zn}]_{\mathrm{S}}=51.46-0.03 *[\mathrm{Cr}]_{\mathrm{Ee}}$

$[\mathrm{Pb}]_{\mathrm{S}}=13.50-0.22 *[\mathrm{~Pb}]_{\mathrm{Ee}}$

$[\mathrm{Ni}]_{\mathrm{S}}=11.11-0.01 *[\mathrm{Ni}]_{\mathrm{Ee}}$

$[\mathrm{Cd}]_{\mathrm{S}}=2.53-0.004 *[\mathrm{Cd}]_{\mathrm{Ee}}$

$\begin{array}{ll}0.12 & 0.57 \\ 0.13 & 0.56 \\ 6.11 \times 10^{-5} & 0.99 \\ 0.008 & 0.89 \\ 2.75 \times 10^{-5} & 0.99 \\ 5.07 \times 10^{-5} & 0.99\end{array}$

\section{Lumbricus rubellus}

$\begin{array}{lll}{[\mathrm{Cr}]_{\mathrm{S}}=34.49-2.099 *[\mathrm{Cr}]_{\mathrm{Lr}}} & 0.12 & 0.57 \\ {[\mathrm{Cu}]_{\mathrm{S}}=44.19-0.88 *[\mathrm{Cu}]_{\mathrm{Lr}}} & 0.07 & 0.68 \\ {[\mathrm{Zn}]_{\mathrm{S}}=59.11+0.09 *[\mathrm{Zn}]_{\mathrm{Lr}}} & 0.00 & 0.98 \\ {[\mathrm{~Pb}]_{\mathrm{S}}=24.04-0.91 *[\mathrm{~Pb}]_{\mathrm{Lr}}} & 0.03 & 0.80 \\ {[\mathrm{Ni}]_{\mathrm{S}}=13.43-0.33 *[\mathrm{Ni}]_{\mathrm{Lr}}} & 0.06 & 0.70 \\ {[\mathrm{Cd}]_{\mathrm{S}}=1.84+0.06 *[\mathrm{Cd}]_{\mathrm{Lr}}} & 0.02 & 0.84\end{array}$

${ }^{a}[\mathrm{M}]_{\mathrm{S}}$ : metal concentration in the substrates $\left(\mathrm{mg} \mathrm{kg}^{-1}\right),[\mathrm{M}]_{\mathrm{Ef}}$ : metal concentration [Cr, $\mathrm{Cu}, \mathrm{Zn}, \mathrm{Pb}, \mathrm{Ni}, \mathrm{Cd}]$ in the tissues of Eisenia fetida $\left(\mathrm{mg} \mathrm{kg}^{-1}\right),[\mathrm{M}]_{\mathrm{Ee}}$ : metal concentration in Eudrilus eugeniae $\left(\mathrm{mg} \mathrm{kg}^{-1}\right)$, $[\mathrm{M}]_{\mathrm{Lr}}$ : metal concentration in Lumbricus rubellus. Regression at $95 \%$ confidence level.
3.4.2. Metal content in earthworm tissues. The metal concentrations ( $\mathrm{Cr}, \mathrm{Cu}, \mathrm{Zn}, \mathrm{Pb}, \mathrm{Ni}, \mathrm{Cd})$ in the tissues of E. fetida, $E$. eugeniae and $L$. rubellus before $\left(0^{\text {th }}\right.$ day) and after vermicomposting ( $90^{\text {th }}$ day) have been depicted in Fig. 7. The metal accumulation capacity of the earthworm species was largely affected by the metal concentration. Significant differences $(p<$ 0.05 ) were observed in the metal concentrations of earthworm tissues of treatments before and after vermicomposting. $E$. eugeniae showed the maximum accumulation of $\mathrm{Cr}$ in their tissues for Ee3. Wang et al. 2009 (ref. 77) reported E. eugeniae to be an important bio-accumulator and bioindicator of environmental contamination, comprising of persistent pollutants like heavy metals. $\mathrm{Cu}$ was efficiently accumulated by all the three species in the treatments: Ef3, Ef4, Ee3, Ee4, Lr3 and Lr4, indicating high affinity of these worms towards $\mathrm{Cu}$. Higher concentration of $\mathrm{Zn}$ was accumulated by E. eugeniae in Ee2. Morgan and Morgan 1999 (ref. 78) and Kizilkaya 2005 (ref. 79) have reported that bioaccumulation may be strongly influenced by physicochemical and edaphic interactions, including factors such as organic matter content, and C-to- $\mathrm{N}$ ratio. The variability in bioaccumulation of metals in earthworm tissues may depend upon interspecific differences in chemical species requirements, physiological and morphological characteristics, ${ }^{\mathbf{8 0}}$ type of species, ecological category of earthworm species, season and several other factors. ${ }^{81}$ Metal accumulation ability of $E$. eugeniae during vermicomposting has been documented by several authors. ${ }^{\mathbf{4 , 8 2 , 8 3}}$ Suthar 2009 (ref. 55) and Yadav and Garg (2011) observed the metal accumulation ability of $E$. fetida. The potential of metal removal by L. rubellus has been observed by. ${ }^{\mathbf{6 7 , 8 5}}$

Earthworm species (E. fetida, E. eugeniae and L. rubellus) have an inherent tendency to accumulate heavy metals in their gut, using low molecular weight, metal chelating, cysteine rich MT

Table 6 Bioaccumulation factor (BAF) of metals in Eisenia fetida, Eudrilus eugeniae and Lumbricus rubellus ${ }^{a}$

\begin{tabular}{|c|c|c|c|c|c|c|}
\hline \multicolumn{7}{|c|}{ Eisenia fetida } \\
\hline Ef1 & $0.18 \pm 0.008 d$ & $0.15 \pm 0.00 \mathrm{c}$ & $0.03 \pm 0.0001 d$ & $0.13 \pm 0.008 d$ & $0.18 \pm 0.02 c$ & $1.09 \pm 0.003 c$ \\
\hline Ef3 & $1.21 \pm 0.03 b$ & $1.29 \pm 0.05 b$ & $0.34 \pm 0.03 b$ & $0.65 \pm 0.03 \mathrm{~b}$ & $0.57 \pm 0.51 b$ & $3.12 \pm 0.05 a$ \\
\hline Ef4 & $0.21 \pm 0.02 \mathrm{~d}$ & $0.38 \pm 0.01 d$ & $0.14 \pm 0.01 c$ & $0.11 \pm 0.006 \mathrm{~d}$ & $0.28 \pm 0.02 c$ & $1.10 \pm 0.02 \mathrm{~b}$ \\
\hline Ef5 & $3.91 \pm 0.04 \mathrm{a}$ & $3.68 \pm 0.01 \mathrm{a}$ & $0.54 \pm 0.007 a$ & $4.65 \pm 0.24 a$ & $3.91 \pm 0.13 a$ & $0.56 \pm 0.009 d$ \\
\hline Ee1 & $0.42 \pm 0.02 \mathrm{~d}$ & $0.29 \pm 0.002 \mathrm{~d}$ & $0.05 \pm 0.00 \mathrm{~d}$ & $0.15 \pm 0.003 c$ & $0.26 \pm 0.01 \mathrm{~d}$ & $1.11 \pm 0.06 \mathrm{~d}$ \\
\hline $\mathrm{Ee} 2$ & $1.10 \pm 0.08 c$ & $0.22 \pm 0.04 d$ & $0.31 \pm 0.14 \mathrm{~b}$ & $0.74 \pm 0.07 \mathrm{~b}$ & $0.89 \pm 0.07 b$ & $1.69 \pm 0.03 c$ \\
\hline Ee3 & $2.44 \pm 0.02 b$ & $1.33 \pm 0.05 b$ & $0.63 \pm 0.03 b$ & $0.89 \pm 0.10 b$ & $3.31 \pm 0.30 \mathrm{~b}$ & $2.74 \pm 0.62 \mathrm{~b}$ \\
\hline $\mathrm{Ee} 4$ & $1.19 \pm 0.22 c$ & $0.61 \pm 0.10 c$ & $0.20 \pm 0.14 \mathrm{c}$ & $0.57 \pm 0.16 \mathrm{~d}$ & $0.34 \pm 0.002 \mathrm{a}$ & $1.25 \pm 0.04$ \\
\hline Ee5 & $1.49 \pm 0.08 \mathrm{a}$ & $2.43 \pm 0.12 \mathrm{a}$ & $1.54 \pm 0.06 a$ & $1.93 \pm 0.03 a$ & $1.35 \pm 0.36 \mathrm{c}$ & $2.10 \pm 0.45 c$ \\
\hline Lr4 & $0.33 \pm 0.07 d$ & $0.35 \pm 0.05 c$ & $0.10 \pm 0.006 b$ & $0.03 \pm 0.02 \mathrm{~d}$ & $0.28 \pm 0.04 \mathrm{c}$ & $4.39 \pm 0.03 \mathrm{~d}$ \\
\hline Lr5 & $3.44 \pm 0.003 a$ & $0.84 \pm 0.00 \mathrm{~b}$ & $0.31 \pm 0.01 \mathrm{a}$ & $2.38 \pm 0.09 a$ & $0.96 \pm 0.05 b$ & $2.01 \pm 0.10 c$ \\
\hline
\end{tabular}

${ }^{a}$ Values are in mean $\pm \mathrm{SD}(n=7)$. Different letters in the same column represent significant differences (at $\left.p<0.05\right)$ in bioaccumulation factor of earthworm species in different treatments. 
proteins,${ }^{86}$ present in the chloragogenous tissues of their gut. MT regulates the bioavailability detoxification dynamics of essential and non-essential metals in the earthworm guts. ${ }^{87}$ Earthworms have two concurring metal binding mechanisms as per the previous literature ${ }^{88}$ Firstly, the metals are retained in insoluble calcium phosphate granules or chloragosomes. ${ }^{86}$ Due to this, metals remain insoluble and cannot influence the normal biochemical process in the cytoplasm. ${ }^{\mathbf{8 6}}$ Later, these insoluble metals are chelated by the sulphur donating ligands of MTs and are carried to the chloragogenous tissues of the earthworms' intestines, where they are neutralized. ${ }^{88}$ This metal pathway has been supported with daunting proofs in a recent report of. ${ }^{75}$
A relationship has been derived between the metal concentration of the treatments consisting of FA and CD in different ratios and the metal concentration in the respective earthworm tissues. A comparison of regression models of E. fetida, E. eugeniae and $L$. rubellus have been shown in Table 5. Metal concentration in earthworm species as predictor variables explained the variation in metal concentrations of $\mathrm{Cr}, \mathrm{Cu}, \mathrm{Zn}$, $\mathrm{Pb}$, Ni and $\mathrm{Cd}$.

\subsection{Bioaccumulation factor}

Bioaccumulation factor, evaluated with respect to the metal concentration in the treatments and earthworms is given in

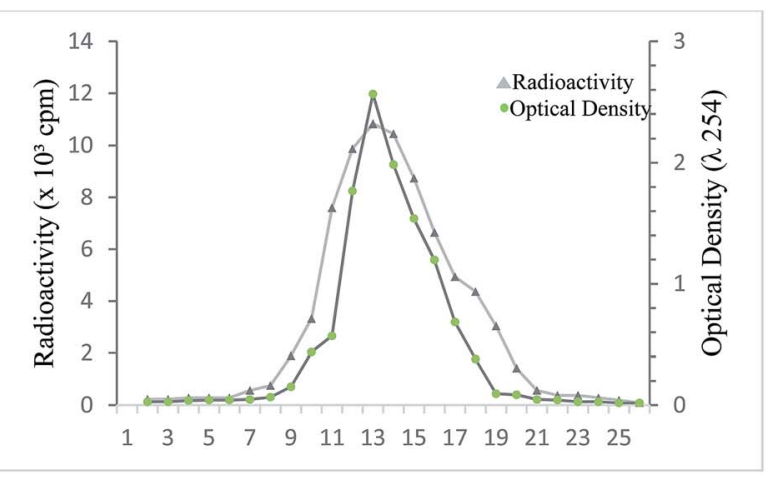

(a)

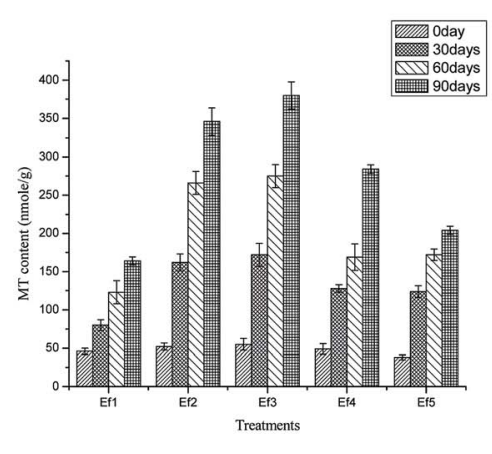

(d)

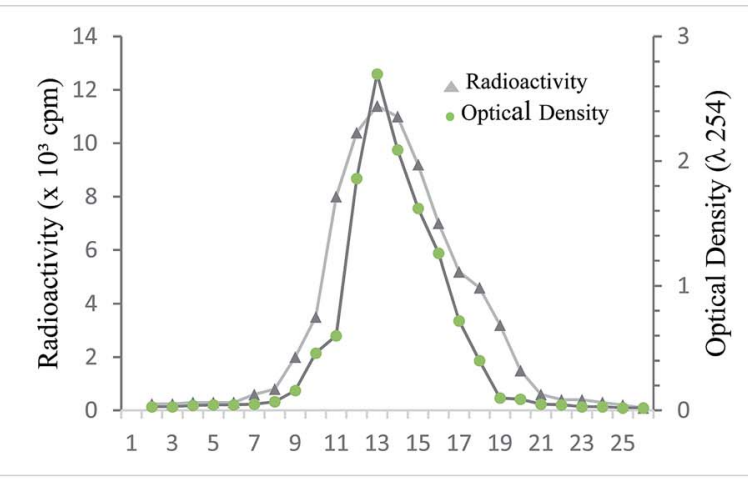

(b)
Eisenia fetida

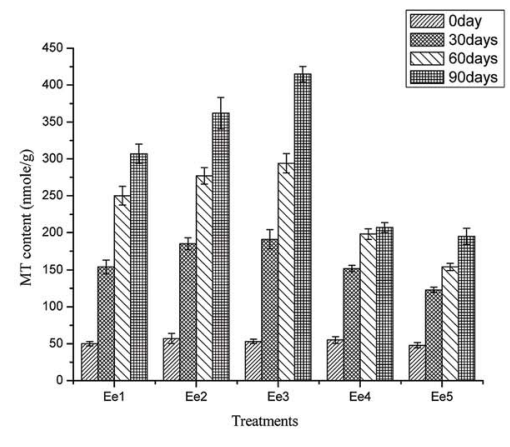

(e)

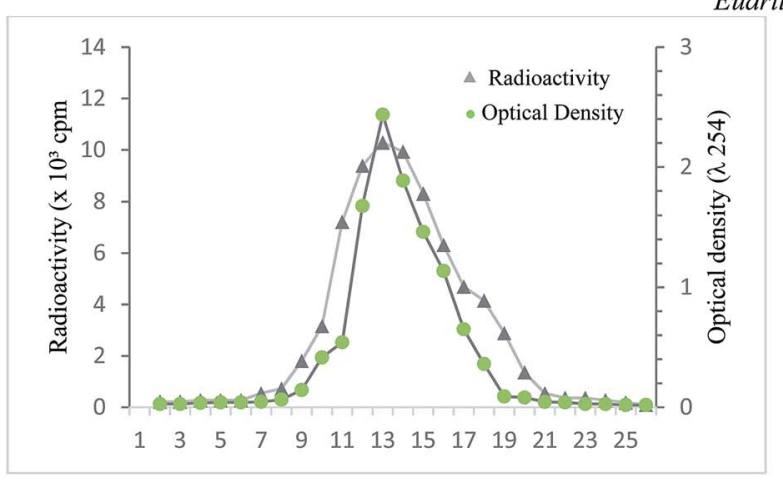

(c)

Lumbricus rubellus

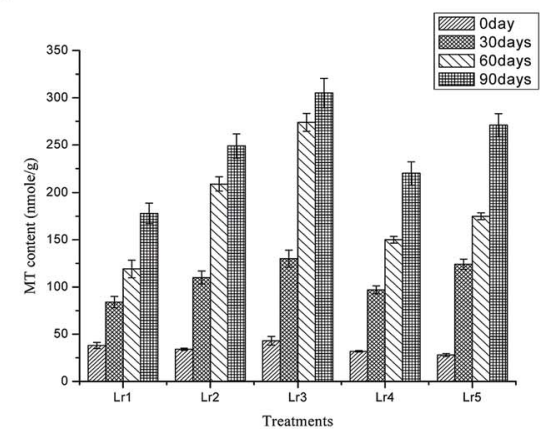

(f)

Fig. 8 (a-c) Elution profiles of sephadex G-75, $\mathrm{Hg}^{203}$ treated acid fractionated supernatant of Eisenia fetida, Eudrilus eugeniae and Lumbricus rubellus tissue. $(\mathrm{d}-\mathrm{f})$ Variation in the level of metallothionein $\left(\mathrm{nmol} \mathrm{g}^{-1}\right)$ in tissues of Eisenia fetida, Eudrilus eugeniae and Lumbricus rubellus on exposure to FA and CD mixtures during the process of vermicomposting. Values are in mean $\pm \mathrm{SD}(n=7)$. Error bars represent standard deviation. 
Table 6. BAF values greater than 1 indicates higher metal concentration in earthworm tissues than that of the substrate. ${ }^{36}$ In case of treatments, comprising E. fetida, BAF was generally found to be below 1, except for Ef3 and Ef5 in case of $\mathrm{Cr}$ and $\mathrm{Cu}$, Ef5 in case of $\mathrm{Pb}$ and $\mathrm{Ni}, \mathrm{Ef} 1$ and $\mathrm{Ef} 4$ for Cd. In case of $E$. eugeniae, the highest value of BAF was found for $\mathrm{Ni},(3.31)$ in Ee3, indicating higher metal concentration in earthworm tissues as compared to other treatments. High BAF values for Cd were found in Ee3 followed by Ee $5>$ Ee $2>$ Ee4. Treatments comprising L. rubellus, Lr4 showed the highest BAF value for Cd followed by $\operatorname{Lr} 2>\operatorname{Lr} 3>\operatorname{Lr} 5>\operatorname{Lr} 1$, while, treatment Lr3 showed the highest BAF value for Ni.

Bioaccumulation is a direct biological measure of metal bioavailability as it measures the actual amount of metal uptake by the earthworm over the duration of earthworm exposure to the substrate. ${ }^{89}$ BAF for metals vary widely with the specific metal, the specific organism, age of the specific organism and specific exposure circumstances determined. Different metals have different chemical properties and different earthworm species have their specific physiological behaviors under different life stages. ${ }^{89}$ A combination of these factors contributes to the variation in metal bioaccumulation as evaluated by BAFs.

\subsection{Variation in metallothionein content}

The sephadex G-75 elution profile of $\mathrm{Hg}^{203}$ incubated and acid fractionated supernatant of E. fetida, E. eugeniae and L. rubellus were demonstrated on radioactive absorbance of $254 \mathrm{~nm}$ peak (Fig. 8a-c). This determines the accuracy of MT radioassay. Exposure to heavy metals induces synthesis of MT isoforms in earthworm intestine,${ }^{20}$ which can detoxify metal ions (As, $\mathrm{Hg}, \mathrm{Si}$, $\mathrm{Al}, \mathrm{Fe}$, etc.) to a considerable extent. ${ }^{22}$ Low molecular mass, MT proteins with very high cysteine content, ${ }^{\mathbf{9 0}}$ have a high affinity towards certain trace metal ions like copper, cadmium and zinc. ${ }^{91}$ The cysteine residues form ligands using thiolate bonds with metal atoms. ${ }^{\mathbf{9 1}}$ Assessment of MT radioactivity is necessary inorder to characterize the mechanism of metal accumulation. ${ }^{92,93}$ There was a substantial increase in MT levels in $E$. fetida, E. eugeniae and L. rubellus (Fig. 8d-f). Maximum MT content was observed in treatment Ee3 $\left(415 \mathrm{nmol} \mathrm{g}^{-1}\right)$ followed by Ef3 $\left(380 \mathrm{nmol} \mathrm{g}^{-1}\right)$, and $\operatorname{Lr} 3\left(305 \mathrm{nmol} \mathrm{g}^{-1}\right)$. The trend for the elution profile of sephadex G-75 and the MT content showed the following order: E. eugeniae $>$ E. fetida $>$ L. rubellus. MT content was maximum in E. fetida for the treatment Ef3 (FA + CD; $1: 3$ ), while in E. eugeniae, MT content was highest for Ee2 (FA + CD; $1: 1)$. The treatment Lr3 showed the maximum MT content for L. rubellus. Goswami et al. (2016) ${ }^{73}$ also observed significantly high level of MT in E. fetida on exposure to metal loaded tea factory coal ash mixtures.

\section{Conclusion}

The study concludes that earthworms holds an important role in processing FA into organic rich manure free from metals. Earthworm species played an important role in enhancing the nutrient content of FA and CD associated mixtures. E. eugeniae showed better overall metal removal efficiency from the treatments as compared to E. fetida and L. rubellus. E. eugeniae showed more affinity towards accumulation of $\mathrm{Cr}, \mathrm{Cu}, \mathrm{Zn}, \mathrm{Cd}$ and $\mathrm{Pb}$ followed by $E$. fetida. MT content showed synchrony with the level of metal accumulation in earthworms. The most effective results in terms of nutrient content and metal remediation was shown for FA + CD $(3: 1)$ mixture. Thus, vermicomposting of coal FA appears viable mostly at low incorporation rates ranging from $33 \%$ to $50 \%$. These application rates may not be a serious challenge as the heavy metals emanating from FA composting can be efficiently remediated by the earthworms thus, falling within permissible limits outlined for other waste. The regression equations derived relations between metal concentration in the treatments and worm tissues of respective substrates, thus supporting the importance of uptake of these metals by the different species of earthworms. Studies related to the impact of metals on the earthworm's cell structure and genes should be done in order to safely and properly execute the vermicomposting process of coal FA.

\section{Acknowledgements}

The authors are grateful to the Department of Environmental Science and Engineering and Central research facility, Indian Institute of Technology (Indian School of Mines), Dhanbad for providing research facilities.

\section{References}

1 V. Kumar, G. Singh and R. Rai, Fly ash Utilization Programme (FAUP) TIFAC, DST, New Delhi, 2005.

2 G. N. Chattopadhyay and S. S. Bhattacharya, Proceedings of coal ash utilization, 2010, p. 36.

3 R. P. Singh, A. K. Gupta, M. H. Ibrahim and A. K. Mittal, Rev. Environ. Sci. Bio/Technol., 2010, 9, 345-358.

4 D. C. Adriano, A. L. Page, A. A. Elseewi, A. C. Chang and I. A. Straughan, J. Environ. Qual., 1980, 9, 333-344.

5 Z. T. Yao, X. S. Ji, P. K. Sarker, J. H. Tang, L. Q. Ge, M. S. Xia and Y. Q. Xi, Earth-Sci. Rev., 2015, 141, 105-121.

6 S. S. Bhattacharyaa, W. Iftikar, B. Sahariaha and G. N. Chattopadhyay, Resour., Conserv. Recycl., 2012, 65, 100-106.

7 V. C. Pandey, P. C. Abhilash, N. Upadhyay and D. D. Tewari, J. Hazard. Mater., 2009, 166, 255-259.

8 V. C. Pandey and N. Singh, Agric., Ecosyst. Environ., 2010, 136, 16-27.

9 C. Lazcano, M. Gomez-Brandon and J. Dominguez, Chemosphere, 2008, 72, 1013-1019.

10 Z. A. Hickman and B. J. Reid, Environ. Int., 2008, 34, 10721081.

11 S. S. Bhattacharya and G. N. Chattopadhyay, J. Environ. Qual., 2002, 31(6), 2116-2119.

12 S. S. Bhattacharya and G. N. Chattopadhyay, Waste Management \& Research, 2004, 22, 488-491.

13 S. K. Gupta, A. Tewari, R. Srivastava, R. C. Murthy and S. Chandra, Water, Air, Soil Pollut., 2005, 163, 293-302. 
14 S. Suthar, Ecol. Eng., 2008, 32(3), 206-214.

15 A. A. Bakar, N. Z. Mahmood, J. A. Teixeira da Silva, N. Abdullah and A. A. Jamaludin, Biotechnol. Bioprocess Eng., 2011, 16, 1036.

16 S. Suthar, S. Singh and S. Dhawan, Ecol. Eng., 2008, 32, 99107.

17 M. K. Hughes, N. W. Lepp and D. A. Phipps, Adv. Ecol. Res., 1980, 11, 218-237.

18 W. N. Beyer, Appelhof, 1. Proc., Beech Leaf Press, Kalamazoo, 1981, pp. 137-150.

19 M. P. Ireland, Earthworm Ecology, 1983, pp. 247-265.

20 J. Dai, T. Becquer, J. H. Rouiller, G. Reversat, F. BernhardReversat, J. Nahmani and P. Lavelle, Soil Biol. Biochem., 2004, 36, 91-98.

21 M. G. Vijver, C. A. M. Van Gestel, N. M. Van Straalen, R. P. Lanno and W. J. G. M. Peijnenburg, Environ. Toxicol. Chem., 2006, 25, 807-814.

22 S. Maity, S. Bhattacharya and S. Chaudhury, Chemosphere, 2009, 77, 319-324.

23 N. Chiaverini and M. De Ley, Free Radical Res., 2010, 44, 605613.

24 G. W. Irvine, K. L. Summers and M. J. Stillman, Biochem. Biophys. Res. Commun., 2013, 433, 477-483.

25 D. Singh and S. Suthar, Bioresour. Technol., 2012, 112, 179185.

26 S. R. Olsen, C. V. Cole, F. S. Watanabe and L. A. Dean, Estimation of available phosphorous in soils by extraction with sodium bicarbonate, Circ. US Dep. Agric., 1954, p. 939.

27 A. Walkley and C. A. Black, Soil Sci., 1934, 37, 29-38.

28 J. M. Bremner, Soil Sci. Soc. Am., Madison, WI, 1996, pp. 1085-1122.

29 S. Pawluk, At. Absorpt. Newsl., 1967, 6, 53-56.

30 S. S. Bhattacharya, S. Barman, R. Ghosh, R. K. Duary, L. Goswami and N. C. Mandal Indian, J. Exp. Biol., 2013, 15, 840-848.

31 R. C. Bhangare, P. Y. Ajmal, S. K. Sahu, G. G. Pandit and V. D. Puranik, Int. J. Coal Geol., 2011, 86, 349-356.

32 E. A. Kruse and G. W. Barret, Environ. Pollut., 1985, 38, 235244.

33 S. A. Katz and S. W. Jennis, Regulatory Compliance Monitory by Atomic Absorption Spectrometry, Verlag Chemie International, Florida, 1983.

34 F. N. Kotsonis and C. D. Klaassen, Toxicol. Appl. Pharmacol., 1977, 51, 19-27.

35 J. K. Piotrowski, W. Balanowska and A. Sapota, Acta Biochim. Pol., 1973, 20, 207-215.

36 A. Montouris, E. Voutsas and D. Tassios, Mar. Pollut. Bull., 2002, 44, 1136-1141.

37 R. D. Kale, B. C. Mallesh, K. Bano and D. J. Bagyaray, Soil Biol. Biochem., 1992, 24, 1317-1320.

38 H. Deka, S. Deka, C. K. Baruah, J. Das, S. Hoque, H. Sarma and N. S. Sarma, Bioresour. Technol., 2011, 102, 11212-11217.

39 V. K. Garg and P. Kaushik, Bioresour. Technol., 2005, 96, 1063-1071.

40 R. K. Sinha, S. Agarwal, K. Chauhan and V. Dalsukh, Agric. Sci., 2010, 1(2), 76-94.
41 R. Atiyeh, J. Dominguez, S. Subler and C. A. Edwards, Pedobiologia, 2000, 44, 709-724; J. Dominguez, CRC, Boca Raton, 2004, pp. 401-424.

42 P. L. S. Chan and D. A. Griffiths, Biol. Wastes, 1988, 24(1), 5769.

43 J. W. C. Wong, S. W. Y. Li and M. H. Wong, Environ. Technol., 1995, 16, 527-537.

44 P. Garg, A. Gupta and S. Satya, Bioresour. Technol., 2006, 97, 391-395.

45 J. H. Crawford, Process Biochem., 1983, 8, 14-15.

$46 \mathrm{~J}$. Dominguez, State of the Art and New Perspectives on Vermicomposting Research, ed. C. A. Edwards, CRC Press, Boca Raton, 2004, pp. 401-424.

47 S. Suthar, Bioresour. Technol., 2007, 97, 2474-2477.

48 S. Suthar, Bioresour. Technol., 2007, 98, 1608-1614.

49 M. Khwairakpam and R. Bhargava, J. Hazard. Mater., 2009, 161, 948-954.

50 S. Suthar and S. Singh, Int. J. Environ. Sci. Technol., 2008, 5(1), 99-106.

51 M. Viel, D. Sayag and L. Andre, Optimization of agricultural, industrial waste management through in-vessel composting, ed. de M. Bertoldi, Elseiver Appl. Sci. Essex, 1987, pp. 230237.

52 Kaviraj and S. Sharma, Bioresour. Technol., 2003, 90, 169-173.

53 P. Kaushik and V. K. Garg, Bioresour. Technol., 2003, 90, 311316.

54 G. Tripathi and P. Bhardwaj, Bioresour. Technol., 2004, 92, 275-283.

55 S. Suthar, J. Hazard. Mater., 2009, 163, 199-206.

56 R. Hartenstein and F. Hartenstein, J. Environ. Qual., 1981, 10, 377-382.

57 M. Aira, F. Monroy, J. Dominguez and S. Mato, Eur. J. Soil Biol., 2002, 38, 7-10.

58 M. Aira and J. Dominguez, J. Environ. Manage., 2008, 88, 1525-1529.

59 A. C. Gaur and G. Singh, Recycling of rural and urban waste through conventional and vermicomposting, ed. H. L. S. Tondon, New Delhi, 1995, pp. 31-49.

60 M. Ghosh, G. N. Chattopadhyay and K. Baral, Bioresour. Technol., 1999, 69, 149-154.

61 D. P. Singh and S. K. Dwivedi, Environmental Microbiolgy and Biotechnology, New Age International Limited, Publishers, Lucknow, 2004, pp. 100-241.

62 J. E. Satchell and K. Martein, Soil Biol. Biochem., 1984, 16, 191-194.

63 C. A. Edwards and J. R. Lofty, Chapman and Hall, London, 1972.

64 K. E. Lee, Earthworms: their ecology and relationships with soils and land use, Academic Press, Sydney, 1985, p. 411.

65 S. Ananthakrishnasamy, S. Sarojini, G. Gunasekaran and G. Manimegala, Am.-Eurasian J. Agric. Environ. Sci., 2009, 5, 720-724.

66 V. T. George, S. R. Prabhu, M. Z. Reeny and B. M. Bopaiah, World J. Microbiol. Biotechnol., 1998, 14, 879-882.

67 M. Lores, M. Gomez-Brandon, D. Perez and J. Dominguez, Soil Biol. Biochem., 2006, 38, 2993-2996. 
68 S. S. Bhattacharya and G. N. Chattopadhyay, Nutr. Cycling Agroecosyst., 2006, 75, 223-231.

69 R. Niyazi and S. Chaurasia, Int. J. Pharm., Chem. Biol. Sci., 2014, 4(1), 85-95.

70 L. Z. Li, D. M. Zhou, P. Wang and X. S. Luo, Ecotoxicol. Environ. Saf., 2008, 71, 632-637.

71 X. Song, M. Liu, D. Wu, L. Qi, C. Ye, J. Jiao and F. Hu, Waste Manage., 2014, 34, 1977-1983.

72 B. Sahariah, L. Goswami, K.-H. Kim, P. Bhattacharyya and S. S. Bhattacharya, Bioresour. Technol., 2015, 180, 230-236.

73 L. Goswami, S. Pratihar, S. Dasgupta, P. Bhattacharyya, P. Mudoi, J. Bora, S. S. Bhattacharya and K. H. Kim, Sci. Rep., 2016, 6, 30402, DOI: 10.1038/srep30402.

74 J. Kang, Z. Zhang and J. J. Wang, Bioresour. Technol., 2011, 102, 8022-8026.

75 S. R. Sturzenbaum, M. Hockner, A. Panneerselvam, J. Levitt, J.-S. Bouillard, S. Taniguchi, L.-A. Dailey, R. A. Khanbeigi, E. V. Rosca, M. Thanou, K. Suhling, A. V. Zayats and M. Green, Nat. Nanotechnol., 2012, 8, 57-60.

76 E. Romero, C. Plaza, N. Senesi, R. Nogales and A. Polo, Geoderma, 2007, 139, 397-406.

77 Q. Wang, D. Zhou, L. Cang and H. Zhu, Eur. J. Soil Biol., 2009, 45, 229-234.

78 J. E. Morgan and A. J. Morgan, Appl. Soil Ecol., 1999, 13, 9-20.

79 R. Kizilkaya, Ecol. Eng., 2005, 25(4), 322-331.

80 F. Nannoni, G. Protano and F. Riccobono, Geoderma, 2011, 161, 63-73.

81 D. Das, P. Bhattacharyya, B. C. Ghosh and P. Banik, J. Environ. Sci. Health, Part B, 2012, 47(3), 205-211.
82 B. Ravindran, R. Sravani, A. B. Mandal, S. M. ContrerasRamos and G. Sekaran, J. Therm. Anal. Calorim., 2013, 111(3), 1675-1684.

83 N. Soobhany, R. Mohee and V. K. Garg, Waste Manage., 2015, 39, 130-145.

84 A. Yadav and V. K. Garg, Rev. Environ. Sci. Bio/Technol., 2011, 10, 243-276.

85 D. J. Spurgeon and S. P. Hopkin, Arch. Environ. Contam. Toxicol., 1999, 37(3), 332-337.

86 S. R. Sturzenbaum, P. Kille and A. J. Morgan, FEBS Lett., 1998, 431, 437-442.

87 S. Maity, S. Roy, S. Bhattacharya and S. Chaudhury, Eur. J. Soil Biol., 2011, 47, 69-71.

88 A. J. Morgan, J. E. Morgan, M. Turner, C. Winters and A. Yarwood, Metal relationship of earthworms, in Ecotoxicology of Metals in Invertebrates, ed. R. Dallinger and P. S. Rainbow, Lewis Publishers, Boca Raton, FL, USA, 1993, pp. 333-358.

89 S. Yu and M. S. Dissertation, Bioaccumulation of metals in earthworm, The Ohio State University. Proquest, East Eisenhower Parkaway, Ann Arbor, 2009, p. 173, 3393268.

90 S. Demuynck, F. Grumiaux, V. Mottier, D. Schikorski, S. Lemiere and A. Leprêtre, Comp. Biochem. Physiol., Part C: Toxicol. Pharmacol., 2006, 144, 34-46.

91 R. Dallinger, Appl. Biochem. Biotechnol., 1994, 48(1), 27-31.

92 M. Hockner, R. Dallinger and S. R. Sturzenbaum, J. Biol. Inorg Chem., 2011, 16, 1057-1065.

93 M. Hockner, R. Dallinger and S. R. Stürzenbaum, Biochem. Biophys. Res. Commun., 2015, 460, 537-542. 